\title{
Simultaneous detection of white spot syndrome virus (WSSV) and Taura syndrome virus (TSV) by multiplex reverse transcription-polymerase chain reaction (RT-PCR) in Pacific white shrimp Penaeus vannamei
}

\author{
Jyh-Ming Tsai ${ }^{1, *}$, Lin-John Shiau ${ }^{1}$, Hsien-Hsiung Lee ${ }^{2}$, Peter W. Y. Chan ${ }^{1,2}$, \\ Ching-Yu Lin ${ }^{2}$
}

${ }^{1}$ King Car Biotechnology Industrial Co., Ltd, Aquaculture Research and Development Center, No. 162-13 Qi Wu Lan Road, Jiao-Xi Xiang, I-Lan 266, Taiwan, ROC

${ }^{2}$ King Car Food Industrial Co., Ltd. Yuan-Shan Research Institute, No. 86 Chen-Hsiang Road, Yuan-San Xiang, I-Lan 264, Taiwan, ROC

\begin{abstract}
An assay using a single-tube, 1-step multiplex reverse transcription-polymerase chain reaction (RT-PCR) was established for the simultaneous detection of white spot syndrome virus (WSSV) and Taura syndrome virus (TSV). Three primer sets, 9195 F/9992 R, 94 F2/R2, and ITS F/28S $\mathrm{R}$, were mixed at a ratio of 3:1:1 to amplify specific fragments of the TSV, WSSV, and Penaeus vannamei genome, respectively, in the RT-PCR reaction. Shrimp samples were experimentally infected with WSSV and TSV. PCR-amplified products detected in the nucleic acid extraction of shrimp pleopods produced 4 kinds of results. With no virus infection, 1 fragment of 892 base pairs (bp) was amplified from a ribosomal RNA gene by primer set ITS F/28S R as an internal control. In samples only infected by WSSV or TSV, 2 fragments could be seen: either from WSSV (530 bp) plus the internal control or TSV (231 bp) plus the internal control, respectively. In cases of co-infection with both viruses, all 3 amplified products were detected simultaneously. This study is the first report of Penaeus vannamei specimens co-infected with WSSV and TSV being detected using a PCR method via experimental infection.
\end{abstract}

KEY WORDS: RT-PCR $\cdot$ WSSV $\cdot$ TSV $\cdot$ Penaeid shrimp

Resale or republication not permitted without written consent of the publisher

\section{INTRODUCTION}

Over the past several years, white spot syndrome virus (WSSV) has devastated the tiger shrimp Penaeus monodon culture industry in Taiwan and other Asian countries (Lo \& Kou 1998). Penaeus vannamei (Pacific white shrimp, also called Litopenaeus vannamei) was introduced into Taiwan from the Americas; many farm-

${ }^{*}$ Present address: National Taiwan University, Department of Zoology, Taipei 106, Taiwan, ROC.

E-mail: anguilla@cm1.hinet.net ers switched to raising this newly introduced species. By early 1998, $P$. vannamei had become the most popular and highest yield cultured shrimp in southern Taiwan. However, from late 1998 to early 1999, due to importation of Taura syndrome virus (TSV)-contaminated post larvae (PL) or spawners, there were outbreaks of Taura syndrome in cultured Pacific white shrimp (Tu et al. 1999, Yu \& Song 2000). Shrimp production dramatically dropped to as low as $10 \%$ of the production level in early 1998. After the introduction of $P$. vannamei, both WSSV and TSV have become important shrimp viral pathogens in Taiwan. WSSV has a 
wide host range among crustaceans (Flegel 1997) and distinctive clinical signs (white spots) in penaeid shrimps. The entire sequence of the double-stranded, circular DNA genome has been determined (van Hulten et al. 2001). TSV is a single-stranded RNA virus that causes serious disease in the PL, juvenile and adult stages of $P$. vannamei exclusively (Lightner \& Redman 1998).

Reverse transcription (RT) and polymerase chain reaction (PCR) technologies have proven to be powerful diagnostic tools for shrimp viral infections and for detection of viral reservoirs in asymptotic carriers. Methods for PCR diagnosis have been published for WSSV (Kimura et al. 1996, Lo et al. 1996, Takahashi et al. 1996, Kim et al. 1998, Tapay et al. 1999) and TSV (Nunan et al. 1998). This study was carried out to develop a modified method using a template comprised of total nucleic acid for simultaneous detection of WSSV and TSV in a single tube, 1-step multiplex RT-PCR.

\section{MATERIALS AND METHODS}

Experimental infections. Penaeus vannamei, weighing approximately $3.5 \mathrm{~g}$ and originating from a commercial shrimp hatchery in Tungkang, southern Taiwan, were reared from post larvae to the juvenile stage in an indoor recirculation system. Randomly selected specimens were checked using TSV RT-PCR (Nunan et al. 1998) and then WSSV PCR (Lo et al. 1996), and all were found to be PCR negative. Juveniles were stocked at a density of about 20 shrimp per 901 aquarium tank. Inocula were prepared from patently infected (carapace with white spots) $P$. monodon for WSSV and from $P$. vannamei for TSV. Shrimp collected from cultivation ponds experiencing disease outbreaks in I-lan, north Taiwan, were proven to be virally infected by WSSV PCR and TSV RT-PCR. The carapace was removed from whole moribund specimens, chopped, and fed to juveniles in the tank. The shrimps were initially given $15 \%$ (body weight) infected tissue, and this was repeated $1 \mathrm{~d}$ later. The TSV inoculum was introduced first, and WSSV was given $10 \mathrm{~d}$ later.

Total nucleic acid purification. Pleopods from virustreated Penaeus vannamei were collected from moribund shrimp and other remaining survivors randomly during the period of the bioassay experiment. Pleopods sampled from juveniles on Day 0 were used as the negative control in each experiment. Approximately 15 to $20 \mathrm{mg}$ of pleopod was excised from each specimen. The protocol for total nucleic purification was developed, with modifications, from the procedure of Miller et al. (1988). The pleopods were homogenized in a $1.5 \mathrm{ml}$ microcentrifuge tube with a microcentrifuge pestle. Next, $600 \mu \mathrm{l}$ lysis buffer $(100 \mathrm{mM} \mathrm{NaCl}, 10 \mathrm{mM}$ EDTA, $50 \mathrm{mM}$ Tris-base, pH 7.5, 0.5\% SDS) and $15 \mu \mathrm{l}$ Proteinase $\mathrm{K}$ stock solution $\left(20 \mathrm{mg} \mathrm{ml}^{-1}\right)$ were added to the tube. Each sample was heated to $60^{\circ} \mathrm{C}$ for $30 \mathrm{~min}$ and mixed every $10 \mathrm{~min}$. After incubation, the tube was placed on ice for 3 to $5 \mathrm{~min}$. To remove protein in the sample, $200 \mu \mathrm{l}$ of $10 \mathrm{M} \mathrm{NH}_{4} \mathrm{OAC}$ was added and mixed vigorously before centrifugation at $12000 \times g$ for $10 \mathrm{~min}$ at $4^{\circ} \mathrm{C}$ with a swing bucket rotor. To minimize the risk of contaminating the sample with possible inhibitory compounds in the pellet, only $650 \mu$ of the supernatant was transferred to a new $1.5 \mathrm{ml}$ tube. To precipitate the nucleic acid, $700 \mu \mathrm{l}$ isopropanol was added to the tube, which was inverted several times, and centrifuged for $10 \mathrm{~min}$ at $12000 \times g$ and $4^{\circ} \mathrm{C}$. The pellet was rinsed twice with $500 \mu \mathrm{l} 75 \%$ ethanol and then air dried for 10 to $15 \mathrm{~min}$. The nucleic acid pellet was resuspended in $150 \mu \mathrm{l}$ of DEPC-treated water at $60^{\circ} \mathrm{C}$ for $10 \mathrm{~min}$ and stored at $-20^{\circ} \mathrm{C}$ until use.

Oligonucleotide primers. Several specific primer sets were used in the 1-step multiplex RT-PCR, including: $9195 \mathrm{~F} / 9992 \mathrm{R}$ (Nunan et al. 1998) for TSV; 94 F2/R2 (Tsai et al. 1999) for WSSV; and ITS F/28S R for the internal control (Table 1). The internal control was included so that the quality of extracted nucleic acid and PCR inhibitor conditions could be checked. The primer set ITS F and 28S R was designed from the Internal Transcribed Spacer 2 (ITS2) and 28S rRNA sequences of Penaeus vannamei, based on unpublished sequences available in GenBank under Accession No. GI 5825422 (www.ncbi.nlm.nih.gov/Genbank/ index.html). Shrimp DNA was expected to yield a PCR product of $892 \mathrm{bp}$ pairs corresponding to the nucleotide sequence from Positions 1063 to 1954 of the ribosomal RNA gene in the GenBank data file. These primers were synthesized by Genset Singapore Biotech.

One-step multiplex RT-PCR. Ready-To-Go ${ }^{\mathrm{TM}} \mathrm{RT}$-PCR Beads (Amersham Pharmacia Biotech) were used in each amplification reaction. This kit is designed so that all components for RT and PCR can be run in a single tube by a simple non-interrupted thermal cycle. Each bead in the tube contains M-MuLV reverse transcrip-

Table 1. Nucleotide sequence and melting temperature $\left(T_{\mathrm{m}}\right)$ of the 6 primers used in this study

\begin{tabular}{|llc|}
\hline Primer & Nucleotide sequence & $T_{\mathrm{m}}\left({ }^{\circ} \mathrm{C}\right)$ \\
\hline $9195 \mathrm{~F}$ & 5'-TCAATGAGAGCTTGGTCC & 54 \\
$9992 \mathrm{R}$ & 5'-AAGTAGACAGCCGCGCTT & 56 \\
$94 \mathrm{~F} 2$ & 5'-CGATACTGCCATTGAAAGC & 56 \\
$94 \mathrm{R} 2$ & 5'-GCCCTGGAGAACACTTCC & 58 \\
ITS F & 5'-AAAGGCCGCTACGAGAATCTCT & 55 \\
28S R & 5'-AGGTCGACGTGAGCAAGGAAT & 55 \\
\hline
\end{tabular}


tase, buffer, nucleotide, and Taq DNA polymerase. The only additional reagents required are water, primers, and template. Each oligonucleotide primer was diluted to $10 \mu \mathrm{M}$ of the working solution. Three primer sets for TSV, WSSV, and the internal control were mixed in 1 tube in the ratio of 3:1:1 $(6 \mu \mathrm{M}: 2 \mu \mathrm{M}$ : $2 \mu \mathrm{M})$ as the primer cocktail solution. Each reagent was added to the reaction tube in the following order: $43 \mu \mathrm{l}$ water was added to dissolve the beads, and then the mixture was cooled in an ice bath for $5 \mathrm{~min}$. Next, $5 \mu \mathrm{l}$ primer cocktail solution was added and mixed thoroughly. To reduce the cost, the original final volume $(50 \mu \mathrm{l})$ of each reaction was halved (to $25 \mu \mathrm{l}$ ). Twenty-four $\mu$ l of reaction solution was transferred to a new PCR tube for the other reaction, and finally, $1 \mu \mathrm{l}$ shrimp nucleic acid was added to both tubes as a template. Each tube was incubated in a thermal cycler (PE 9700; Perkin Elmer) set to the following program: $15 \mathrm{~min}$ at $42^{\circ} \mathrm{C}$ (for $\mathrm{RT}$ reaction), then $4 \mathrm{~min}$ at $95^{\circ} \mathrm{C}$ (for inactivation of reverse transcriptase and denaturation of DNA); 40 cycles of $94^{\circ} \mathrm{C}$ for $1 \mathrm{~min}, 55^{\circ} \mathrm{C}$ for $2 \mathrm{~min}$, and $72^{\circ} \mathrm{C}$ for $2 \mathrm{~min}$, followed by a final incubation for $7 \mathrm{~min}$ at $72^{\circ} \mathrm{C}$. The amplified product was analyzed following electrophoresis $(100 \mathrm{~V}, 30 \mathrm{~min})$ in $2 \%$ agarose gels stained with ethidium bromide.

\section{RESULTS AND DISCUSSION}

During the experimental infections, there were no obvious acute-phase mortalities among samples after TSV experimental infection. The inoculum was prepared from crude samples of virus-infected shrimp which were fed directly to juveniles, not by injection as done, for example, by Nunan et al. (1998). Thus, it is possible that some Penaeus vannamei survived into the chronic phase of TSV infection, and then were coinfected with the WSSV inoculum.

With the method described here, 3 kinds of viral infections were detected using nucleic acids from shrimp pleopods (Fig. 1). One internal control fragment of $892 \mathrm{bp}$ was the only fragment amplified by the internal control primer set from the negative control shrimp. Two fragments displayed single infection with either WSSV or TSV, from WSSV a 530 bp fragment plus the internal control, and from TSV a 231 bp fragment plus the internal control. In cases of co-infection by both viruses, all 3 amplified products were observed in the agarose gel. Wongteerasupaya et al. (1995) reported a Penaeus monodon specimen experimentally co-infected with WSSV (called systemic ectodermal and mesodermal baculovirus or SEMBV in their paper) and yellow-head virus (YHV) as determined by transmission electron microscopy. Our study is the first report of an experimental co-infection of
WSSV and TSV in P. vannamei being detected using a PCR method.

The multiplex RT-PCR conditions using 3 primer sets were optimized using different primers and mixing ratios. According to the size distribution of the amplified products, the 3 primer sets (9195 F/9992 R, 94 F2/R2, and ITS F/28S R) were used to amplify fragments of 231, 530, and 892 bp respectively. Empirically, the mixing ratio was optimized to $3: 1: 1$ in the primer cocktail solution. Generally, there is a high concentration of ribosomal RNA and DNA in total nucleic acid extracts. Thus, primers specific to ribosomal RNA gene sequences used as the internal control (e.g. as in Lo et al. 1996), would compete with the TSV primers in the reverse transcription step. In order to avoid this unbalanced competition, the reverse primer of the internal control, 28S R, was designed to anneal at the splice junction of the ITS2 and 28S genes (Bagshaw \& Quiel 1998). Thus one-half of the primer was hybridized to the $3^{\prime}$ end of the $28 \mathrm{~S}$ gene and the other half to the $5^{\prime}$ end of the adjacent ITS2 gene. This primer would anneal to ribosomal DNA but not to spliced ribosomal RNA, and this eliminated reverse transcription of rRNA to cDNA.

The extraction procedure used in the sample preparation was easy to carry out, and it yielded nucleic acids including both DNA and RNA from shrimp

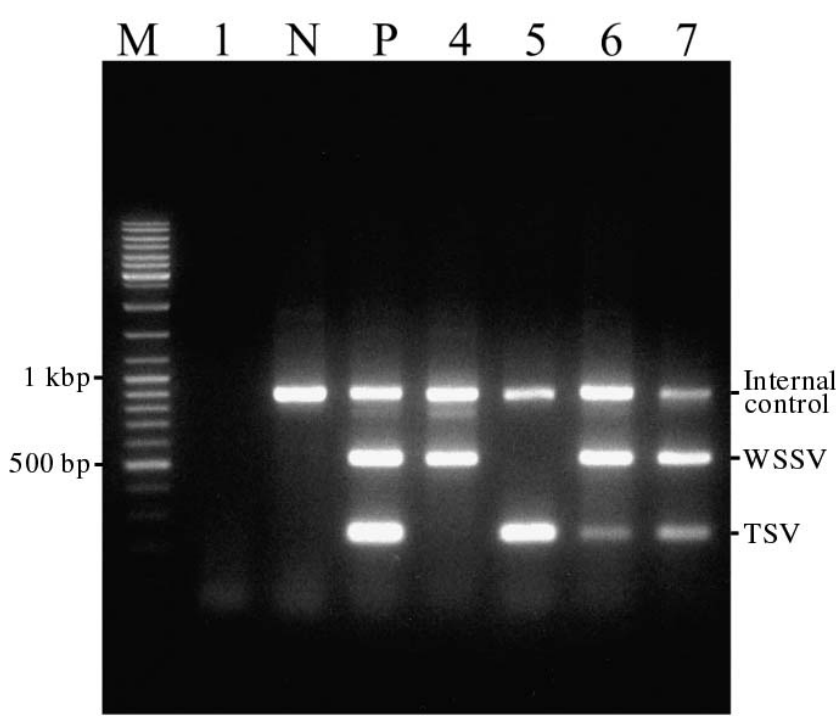

Fig. 1. Agarose electrophoresis gel of RT-PCR products from a multiplex RT-PCR assay using the 3 primer sets, $9195 \mathrm{~F} / 9992$ R, 94 F2/R2, and ITS F/28S R. The nucleic acid from pleopods of experimentally infected Penaeus vannamei was used as the template. Lane M: DNA molecular weight markers; Lane 1: water as the template for RT-PCR; Lane N: no virus infection, Day 0 pleopod as the negative control; Lane P: mixed templates of Lanes 4 and 5 as the positive control; Lane 4 : infected by WSSV only; Lane 5: infected by TSV only; Lanes 6 and 7: co-infection with both viruses, WSSV and TSV 
pleopods. Some problems have been reported with copurification of PCR inhibitors in nucleic acid extraction tests with alternative template sources such as hepatopancreatic tissue and post larvae (Wang et al. 1996, Belcher \& Young 1998). The salting-out procedure does not eliminate inhibitors. A different method, such as CTAB (Lo et al. 1996), should be developed to deal with these kinds of samples.

The Ready-To-Go dry beads are designed to be stable at room temperature, enabling temperaturesensitive enzymes to be carried on trips for viral disease screening at farms. In the case of screening post larvae or broodstock, where greater sensitivity is required, the Ready-To-Go system may prove less sensitive than other reagents. This could potentially be overcome by the use of nested PCR.

In routine testing of large numbers of Penaeus vannamei specimens in the culture industry, this the 1-step multiplex RT-PCR method described above may be useful for simultaneous detections of WSSV and TSV.

\section{LITERATURE CITED}

Bagshaw JC, Quiel E. JA (1998) Structure and polymorphism of ribosomal RNA genes in the marine shrimp Penaeus vannamei. Aquaculture 159:333-343

Belcher CR, Young PR (1998) Colorimetric PCR-based detection of monodon baculovirus in whole Penaeus monodon postlarvae. J Virol Methods 74:21-29

Flegel TW (1997) Major viral diseases of the black tiger prawn (Penaeus monodon) in Thailand. World J Microbiol Biotechnol 13:433-442

Kim CK, Kim PK, Sohn SG, Sim DS and 6 others (1998) Development of a polymerase chain reaction (PCR) procedure for the detection of baculovirus associated with white spot syndrome (WSBV) in penaeid shrimp. J Fish Dis 21:11-17

Kimura T, Yamano K, Nakano H, Momoyama K, Hiraoka M, Inouye K (1996) Detection of penaeid rod-shaped DNA virus (Prdv) by PCR. Fish Pathol 31:93-98

Editorial responsibility: Carey Cunningham, Aberdeen, Scotland, UK
Lightner DM, Redman RM (1998) Strategies for the control of viral diseases of shrimp in the Americas. Fish Pathol 33: $165-180$

Lo CF, Kou GH (1998) Virus-associated white spot syndrome of shrimp in Taiwan: a review. Fish Pathol 33:365-371

Lo CF, Leu JH, Ho CH, Chen CH and 8 others (1996) Detection of baculovirus associated with white spot syndrome (WSBV) in penaeid shrimps using polymerase chain reaction. Dis Aquat Org 25:133-141

Miller SA, Dykes DD, Polesky HF (1988) A simple salting out procedure for extracting DNA from human nucleated cells Nucleic Acids Res 16:1215

Nunan LM, Poulos BT, Lightner DV (1998) Reverse transcription polymerase chain reaction (RT-PCR) used for the detection of Taura syndrome virus (TSV) in experimentally infected shrimp. Dis Aquat Org 34:87-91

Takahashi Y, Itami T, Maeda M, Suzuki N and 9 others (1996) Polymerase chain reaction (PCR) amplification of bacilliform virus (RV-Pj) DNA in Penaeus japonicus Bate and systemic ectodermal and mesodermal baculovirus (SEMBV) DNA in Penaeus monodon fabricius. J Fish Dis 19:399-403

Tapay LM, Nadala ECB Jr, Loh PC (1999) A polymerase chain reaction (PCR) protocol for the detection of various geographical isolates of white spot virus (WSV). J Virol Methods 82:39-43

Tsai MH, Kou GH, Liu HC, Liu KF and 5 others (1999) Longterm presence of white spot syndrome virus (WSSV) in a cultivated shrimp population without disease outbreaks. Dis Aquat Org 38:107-114

Tu C, Huang HT, Chuang SH, Hsu JP and 5 others (1999) Taura syndrome in Pacific white shrimp Penaeus vannamei cultured in Taiwan. Dis Aquat Org 38:159-161

van Hullten MC, Witteveldt J, Peters S, Kloosterboer N and 5 others (2001) The white spot syndrome virus DNA genome sequence. Virology 20:7-22

Yu CI, Song YL (2000) Outbreaks of Taura syndrome in Pacific white shrimp Penaeus vannamei cultured in Taiwan. Fish Pathol 35:21-24

Wang SY, Hong C, Lotz JM (1996) Development of a PCR procedure for the detection of Baculovirus penaei in shrimp. Dis Aquat Org 25:123-131

Wongteerasupaya C, Vickers JE, Sriurairatana S, Nash GL and 6 others (1995) A non-occluded, systemic baculovirus that occurs in cells of ectodermal and mesodermal origin and cause high mortality in the black tiger prawn Penaeus monodon. Dis Aquat Org 21:69-77

Submitted: April 30, 2001; Accepted: December 6, 2001

Proofs received from author(s): June 3, 2002 